\title{
Mitos Rambut Gimbal: Identitas Budaya dan Komodifikasi di Dataran Tinggi Dieng
}

\author{
Alfian Febriyanto ${ }^{1}$, Selly Riawanti ${ }^{2}$, Budhi Gunawan ${ }^{2}$ \\ Program Studi Magister Antropologi ${ }^{1}$ \\ Departemen Antropologi ${ }^{2}$ \\ Fakultas Ilmu Sosial dan Ilmu Politik Universitas Padjadjaran \\ Jl. Bukit Dago Utara No. 25 Bandung 40135 \\ alfianfebriyanto90@gmail.com
}

\begin{abstract}
Myths become an integral part of society's social and cultural life. This research examines the myth of rambut gimbal (dreadlock) as the cultural identity that is formed amids cultural commodification. This research finds that the identity formation does not occur at the micro but rather at the meso and makro level. At the meso level, Kelompok Sadar Wisata (Pokdarwis) plays its role in identity formation and the commodification of myth. At the macro level, government's effort to promote rambut gimbal cutting ceremony as one of cultural festivals and tourism commodity demonstrates a formal legitimation of the cultural identity and the myth commodification.
\end{abstract}

Keywords: commodification, Dieng, ethnogenesis, myth, gimbal, identity

\begin{abstract}
Abstrak
Mitos menjadi bagian yang tak terpisahkan dari kehidupan sosial dan budaya masyarakat. Penelitian ini membahas kaitan antara mitos dengan pembentukan identitas budaya pada suatu masyarakat ditengah terjadinya komodifikasi budaya. Penelitian ini menitikberatkan pada kajian mengenai proses pembentukan identitas budaya oleh masyarakat di dataran tinggi Dieng melalui pelestarian mitos rambut gimbal dan proses komodifikasi mitos rambut gimbal. Hasil penelitian menunjukkan bahwa proses pembentukan identitas dan komodifikasi rambut gimbal tidak terjadi di aras mikro tetapi di aras meso dan makro. Pada aras meso, Kelompok Sadar Wisata (Pokdarwis) berperan dalam pembentukan identitas dan komodifikasi mitos. Pada aras makro, pemerintah berperan dalam memberikan legitimasi formal pada identitas yang dibentuk di level meso.
\end{abstract}

Kata kunci: Komodifikasi, Dieng, etnogenesis, mitos, gimbal, identitas

\section{Pendahuluan}

Penelitian ini membahas kaitan antara mitos dengan pembentukan identitas budaya pada suatu masyarakat ditengah terjadinya komodifikasi budaya. Mitos-mitos di berbagai penjuru dunia telah banyak menjadi bahan kajian dengan menggunakan berbagai pendekatan, termasuk pendekatan Antropologi. Lévi-Strauss adalah salah satu Antropolog yang mengkaji mitos menggunakan pendekatan
Antropologi struktural. Di dalam bukunya, "The Raw and The Cooked", Strauss mengkaji mitos "Burung-burung Nuri dan Sarang Mereka” di masyarakat Indian Bororo (Ahimsa-Putra, 2001: 141; Lévi-Strauss, 2015). Di Indonesia, kajian tentang mitos juga telah banyak dilakukan khususnya pada berbagai sukubangsa. Penelitian Zöllner (2011) berjudul "Pohon Yeli dan Mitos Wam dalam Agama Orang Yali” di Papua menunjukkan adanya dualisme hubungan antara ritus dan 
mitos. Penelitian Widiyanto (2012) mengenai mitos Maslihe dan adaptasi kultural penduduk Kendahe, Kepulauan Sangihe terhadap bahaya letusan gunung Awu menunjukkan adanya hubungan reproduksi mitos lokal dengan proses adaptasi yang dikembangkan oleh penduduk terhadap bahaya letusan gunung. Penelitian Dandirwalu (2008) tentang mitos asal usul orang Nias dalam konteks masa kini di Desa Sifalagö Gomo (Börönadu) mengungkap terjadinya reproduksi mitos asal usul dan reproduksi sosial sekaligus proses transformasinya dalam kehidupan sosial masyarakat. Penelitian yang dilakukan Leni (2004) dan Fauzan (2013) menjelaskan dan mempertegas pernyataan Lévi-Strauss bahwa mitos itu adalah bentuk cerita yang kacau balau tetapi menggambarkan sebuah pola keteraturan. Van Peursen (dikutip oleh Daeng, 2008: 81-82) berpendapat bahwa mitos dapat membantu manusia untuk menghayati hal-hal yang mempengaruhi dan menguasai alam dan kehidupan sukubangsanya. Penelitian mitosmitos diatas sama-sama menunjukkan bahwa mitos sebagai bentuk dari dunia mistis selalu berkaitan erat dengan sukubangsa tertentu. Akan tetapi, penelitian-penelitian mitos diatas belum ada yang mengkaji tentang komodifikasi mitos; seperti yang akan dibahas dalam penelitian ini.

Penelitian mengenai rambut gimbal memang telah banyak dilakukan. Penelitian Arif (2013) misalnya, menekankan pada makna simbolik ruwatan cukur rambut gimbal. Penelitian Damayanti (2011) berupaya untuk menjelaskan dinamika perilaku "nakal” yang melekat pada anak berambut gimbal sebagai titisan Kolodete. Penelitian Martiarini (2011) membahas studi pustaka mengenai ruwat rambut gimbal sebagai bentuk penyembuhan simbolik atau symbolic healing. Penelitian Mutmainah (2013) berupaya mengetahui, menggambarkan, dan menjelaskan perilaku sosial anak usia dini dan pengaruh perlakuan orang tua terhadap perilaku sosial anak usia dini berambut gimbal. Penelitian Soehadha (2013) menekankan pada kajian agama dan perubahan sosial akibat ekspansi pasar pariwisata di dataran tinggi Dieng, dan hubungannya dengan kapitalisme negara.

Penelitian-penelitian tersebut adalah bukti bahwa rambut gimbal telah dikaji melalui berbagai perspektif. Namun, diantara penelitian tersebut tidak ada yang menitikberatkan pada kajian mengenai kaitan antara mitos rambut gimbal dengan proses pembentukan identitas masyarakat dataran tinggi Dieng dan komodifikasi mitos rambut gimbal.

\section{Kajian Pustaka: Etnogenesis}

Etnogenesis merupakan penjelasan mengenai proses terbentuknya suatu sukubangsa yang mencakup mitos sebagai pembentuk identitasnya (Bouchard dalam Brix, 2006: 848-849). Menurut Barth (dalam Callister, Didham, dan Kivi, 2009), pembentukan identitas terjadi di tiga aras sosial: makro, meso, mikro. Pada aras makro, pembentukan identitas terkait dengan distribusi kekuasaan, kekayaan dan wewenang yang sekaligus menjadi sebuah legitimasi identitas. Pada aras meso, pembentukan identitas ditopang oleh institusi-meso yang berperan sebagai penghubung antara negara dengan individu, bisa independen atau diatur oleh negara. Pada aras mikro, pembentukan identitas berlangsung melalui kebiasaan sehari-hari dan gaya hidup. Penelitian ini menggunakan konsep etnogenesis di tiga aras sosial untuk menganalisis proses pembentukan identitas budaya masyarakat dataran tinggi Dieng melalui mitos rambut gimbal.

Konsep komodifikasi merujuk pada upaya penggunaan bagian tubuh manusia hingga budaya yang dimiliki masyarakat untuk direduksi menjadi bahan baku produk yang dapat dijual (Sharp, 2000; Shepherd, 2002). Di dalam konteks pariwisata, konsep komodifikasi budaya merujuk pada upaya pemanfaatan kekhasan budaya, untuk menjadi komoditas pariwisata. Gagasan mengenai komodifikasi budaya menjadi perhatian Antropologi, terutama dalam konteks studi pariwisata (Boissevain, 1996a, 1996b; Greenwood, 1989; Macleod, 1999; Tilley, 1997; dikutip Kirtsoglou dan Theodossopoulos, 
2004). Komodifikasi budaya biasanya dilakukan oleh masyarakat dengan mempertimbangkan aspek otentisitas (keaslian, dan kesakralan (Shepherd, 2002).

\section{Metode Penelitian}

Penelitian ini menggunakan perspektif etnografi untuk menjelaskan kaitan antara mitos rambut gimbal dengan pembentukan identitas pada masyarakat Dataran Tinggi Dieng dan komodifikasi budaya. Unit analisis dalam kajian ini ialah masyarakat dataran tinggi Dieng sebagai pemilik mitos rambut gimbal (aras mikro), Kelompok Sadar Wisata atau Pokdarwis (aras meso), dan pemerintah (aras makro).

Data yang dikumpulkan dalam penelitian ini meliputi: 1) unsur budaya; konstruksi identitas diri, sosial, dan kultural pada aras mikro, meso, makro; 2) pengetahuan masyarakat tentang mitos rambut gimbal, pentingnya mitos bagi kehidupan, dan sistem kekerabatan; 3) komodifikasi mitos rambut gimbal. Data dikumpulkan menggunakan teknik pengamatan terlibat, wawancara mendalam (Endraswara, 2006), metode genealogi (Koentjaraningrat, 1958), metode mencatat hasil pembicaraan dengan para informan, dokumentasi. Sumber data berupa data primer yaitu dari informan (Spradley, 1997: 61; 1979; 1980) dan data sekunder. Pemilihan informan dilakukan dengan menggunakan teknik purposive (Creswell, 2010).

Proses analisis dilakukan oleh penulis sepanjang penelitian berlangsung. Triangulasi data dilakukan dengan melibatkan tineliti untuk menjamin validitas data. Analisis data diawali dengan mengumpulkan semua data mentah. Seluruh catatan lapangan dibaca dan dilihat ulang secara keseluruhan. Catatan lapangan dikategorisasi berdasarkan konsep-konsep etik maupun konsep emik. Kategori-kategori tersebut dilabeli dengan istilah-istilah khusus berdasarkan istilah atau bahasa yang berasal dari para pelaku budaya maupun dari konsep peneliti sendiri, lalu disusun menjadi tematema. Selanjutnya, kategori-kategori tersebut dicari kaitannya agar memiliki alur yang jelas satu sama lain, untuk menghasilkan proposisi yang menjelaskan gejala yang diamati.

Penelitian ini dilakukan di Desa Dieng Kulon, Kecamatan Batur, Kabupaten Banjarnegara dan di Desa Dieng (Dieng Wetan), Kecamatan Kejajar, Kabupaten Wonosobo. Kedua desa tersebut dijadikan lokasi penelitian karena merupakan pusat dari peradaban masyarakat dataran tinggi Dieng. Di kedua wilayah itu masih banyak ditemukan anak rambut gimbal, tempat asal usul berkembangnya mitos rambut gimbal, dan tempat mitos rambut gimbal dikomodifikasi.

\section{Hasil Penelitian}

\section{Budaya Masyarakat Dataran Tinggi Dieng}

Penamaan suatu kelompok suku bangsa (etnonimi) dapat dilakukan secara eksonim (diberikan oleh pihak luar) atau otonimi (diciptakan oleh anggota suku bangsa tersebut (Callister, Didham, dan Kivi, 2009: 8). Selain itu, penamaan suatu suku bangsa juga berkaitan dengan kekuatan politik yang melekat (Eriksen 2010: 109). Penamaan Dieng konon tercipta dari eksonimi dan otonimi. Kata Dieng konon berasal dari bahasa Sansekerta "Di" yang berarti tempat yang tinggi atau gunung dan "Hyang" yang berarti dewa. Kata Dieng juga dapat berarti "Edi tur Aeng” (Indah dan Langka/Khayal).

Dataran Dieng adalah salah satu pusat pertanian hortikutura di Provinsi Jawa Tengah. Mata pencaharian utama warga masyarakat bertumpu pada sektor pertanian. Komoditas utama pertanian di Dieng adalah kentang. Kentang varietas baru selalu diperkenalkan pemerintah untuk meningkatkan tingkat produksi, dan dibarengi oleh pembangunan infrastruktur jalan dari dan ke Dieng untuk membuka akses masyarakat pada pasar dan industri berskala nasional. 
Kini, pertanian bukan satu-satunya sumber mata pencaharian warga masyarakat. Sektor baru, yaitu pariwisata mulai menarik minat warga masyarakat. Penataan Dieng sebagai tujuan wisata gencar dilakukan oleh pemerintah. Hal tersebut dipicu oleh agenda politik ekonomi negara modern untuk meningkatkan kesejahteraan masyarakat.

Barker (2013: 175) menyatakan bahwa identitas sosial budaya merupakan konstruksi diskursif yang berubah maknanya menurut ruang, waktu dan pemakaian. Seringkali perubahan identitas dipengaruhi dari luar masyarakat itu sendiri.

Pembentukan identitas budaya Dieng dipengaruhi oleh dua kategori utama yaitu kepercayaan (aliran kepercayaan Kejawen, Hindu, Islam) dan pemerintahan (Kolonial Hindia-Belanda dan pemerintah Indonesia pasca kemerdekaan). Aliran kepercayaan Kejawen sudah dianut masyarakat Dieng jauh sebelum masuknya agama Hindu. Masuknya agama Hindu di Dieng mendorong munculnya dominasi peradaban Hindu yang dibuktikan dengan dibangunnya candi-candi di Dieng. Namun, setelah kedatangan Islam di tanah Jawa, peradaban Hindu di Dieng pun runtuh, dan digantikan dengan peradaban Islam yang berlangsung hingga sekarang.

Kedatangan Kolonial Hindia-Belanda membuat identitas budaya masyarakat Dieng semakin beragam. Pemerintah kolonial membawa serta para pekerja pribumi dari luar wilayah dataran tinggi Dieng. Kedatangan para migran pada awalnya memicu terjadinya diferensiasi antara penduduk migran dan penduduk asli. Namun, lambat laun, kedua kelompok penduduk pada akhirnya berbaur menjadi satu identitas, yaitu "Wong Dieng" (orang Dieng).

Kekhasan budaya dapat dilihat dari kepercayaan yang dianut, bahasa, dan matapencaharian. Mayoritas penduduk Dieng beragama Islam, sebagian beragama Kristen dan Penghayat Kepercayaan Kejawen (meskipun tidak tercantum dalam data kependudukan). Tidak ada lagi warga yang beragama Hindu. Masyarakat menggunakan bahasa Jawa dialek Banyumasan bagian timur tetapi dengan aksen dataran tinggi Dieng. Dengan demikian, dilihat dari sejarahnya, identitas masyarakat dataran tinggi Dieng selalu berubah mengikuti perkembangan jaman.

\section{Mitos Rambut gimbal}

Salah ciri khas budaya masyarakat dataran tinggi Dieng adalah anak-anak dengan rambut gimbal mitos terkait rambut gimbal. Kepercayaan tentang rambut gimbal sudah berkembang menjadi mitos yang melekat pada masyarakat dataran tinggi Dieng. Masyarakat Dieng percaya bahwa anak-anak yang terlahir dengan rambut gimbal karena ia adalah: 1) anak titipan Tumenggung Kolodete, atau 2) keturunan dari orang tua yang rambutnya gimbal. Masyarakat Dieng mempercayai Kolodete sebagai seorang resi Hindu yang menjadi penjaga wilayah Dieng tengah. Masyarakat juga mempercayainya sebagai baureksa (penguasa atau penjaga) sekaligus dhanyang dan sosok yang memberikan pengayoman di dataran tinggi Dieng. Tumenggung Kolodete juga dipercaya sebagai nenek moyang masyarakat dataran tinggi Dieng. Masyarakat Dieng ada yang menganggap rambut gimbal adalah sebuah berkah (Martiarini, 2011: 8) dan ada pula yang menganggapnya sebagai sukerta atau masalah (Disparbud kab. Wonosobo, 2013: 18).

Rambut gimbal dapat terlihat sejak lahir atau baru muncul dikisaran usia 1 sampai 5 tahun. Pada anak-anak yang rambut gimbalnya muncul setelah lahir, mereka akan mengalami masa sakit-sakitan menjelang kemunculan rambut gimbalnya. Mereka biasanya panas yang sangat tinggi, kejang-kejang, sering pingsan, tak kunjung sembuh meskipun sudah ditangani secara medis. Gejala tersebut biasanyadibarengi dengan kemunculan rambut gimbal; dan penyakit si anak akan reda apabila rambut gimbal sudah terbentuk sempurna.

Rambut gimbal tidak boleh dicukur sembarangan. Pencukuran rambut gimbal 
hanya dapat dilakukan jika si anak pemilik rambut gimbal sudah meminta dan menyebutkan bebono ${ }^{1}$ yang diinginkannya. Pencukuran pun tidak boleh dilakukan oleh sembarang orang. Pencukuran biasanya dilakukan oleh pemangku adat, tokoh masyarakat yang mengerti tata caranya, maupun orang yang secara khusus ditunjuk oleh si anak untuk memotong rambut gimbalnya. Masyarakat percaya bahwa anak berambut gimbal yang tidak melakukan upacara tradisi ruwat rambut gimbal akan mengalami gangguan jiwa ketika dewasa. Rangkaian upacara pencukuran meliputi penyediaan sesaji untuk upacara selametan untuk memenuhi bebono pencukuran, dan pelarungan rambut gimbal. Pelaksanaan upacara tradisi ruwat rambut gimbal dilaksanakan secara adat serta disesuaikan dengan ajaran agama Islam.

Komponen yang ada dalam mitos rambut gimbal di Dieng meliputi cerita asal usul, keterlibatan aktor seperti anak berambut gimbal dan tokoh masyarakat, upacara tradisi, sesaji, bebono, mencukur, hingga melarung. Pembahasan selanjutnya yaitu mengenai etnogenesis masyarakat Dieng dan pembentukan identitas masyarakat dataran tinggi Dieng melalui mitos rambut gimbal yang dibangun pada tiga aras yaitu mikro, meso, makro.

\section{Etnogenesis Masyarakat Dataran Tinggi Dieng}

Schermerhorn, Hutchinson dan Smith (1996: 6) mendefinisikan istilah ethnie sebagai:

\section{A named human population with myths of common ancestry, shared historical memories, one or more elements of common culture, a link with a homeland and a sense of solidarity among at least some of its members.}

\footnotetext{
${ }^{1}$ Bebono atau bebanten (bahasa Jawa Krama) merupakan permintaan yang diinginkan oleh anak rambut gimbal yang dipercayai juga permintaan makhluk gaib yang bersemayam pada dirinya sehingga wajib dipenuhi.
}

Dari penjelasan tersebut dapat disimpulkan adanya enam ciri yang dapat menjadi penanda sebuah sukubangsa yaitu 1) memiliki nama yang sama, 2) memiliki mitos tentang nenek moyang sama, 3) memiliki kenangan sejarah masa lalu bersama, 4) memiliki beberapa unsur budaya yang sama, 5) memilikiikatan dengan tanah airnya, dan 6) memiliki solidaritas yang sama.

Beberapa komponen kesukubangsaan yang dikemukakan oleh Hutchinson dan Smith dapat ditemukan di masyarakat dataran tinggi Dieng. Masyarakat dataran tinggi Dieng merupakan suatu populasi manusia yang memiliki nama dan mitos nenek moyang yang sama yaitu Wong Dieng dan mitos rambut gimbal dengan Kolodete sebagai tokoh sentralnya. Masyarakat dataran tinggi Dieng memiliki kenangan sejarah masa lalu bersama yang dibangun sejak masa Kepercayaan Kejawen hingga saat ini. Mereka memiliki banyak kesamaan unsur budaya secara umum, memiliki jaringan serta keterkaitan dengan tanah airnya yaitu wilayah dataran tinggi Dieng, dan memiliki solidaritas bersama sebagai Wong Dieng. Namun demikian, ciri-ciri ini tidak dapat menjadi alasan yang kuat untuk menyebut masyarakat Dieng sebagai sebuah suku bangsa tersendiri dan terlepas dari suku bangsa Jawa.

Hal mendasar yang menyebabkan wong Dieng tidak tidak dapat disebut sebagai sebuah suku bangsa adalah absennya pengakuan dari dalam masyarakat dataran tinggi Dieng sendiri dan juga pengakuan dari luar masyarakat. Kemunculan suku bangsa baru tidak hanya dilatarbelakangi oleh kesamaan nama dan mitos, kenangan sejarah masa lalu bersama, memiliki banyak kesamaan unsur budaya secara umum, memiliki jaringan serta keterkaitan dengan tanah airnya, memiliki solidaritas bersama saja namun, harus memiliki pengakuan dari dalam dan luar komunitas budaya itu sendiri. Saat ini, masyarakat Dieng lebih memilih menyebut diri mereka sebagai bagian dari suku bangsa Jawa. Hal ini disebabkan karena dominasi budaya Jawa yang sangat kuat. Selain itu, 
pihak dari luar masyarakat Dieng yang menganggap bahwa masyarakat Dieng adalah sebuah suku bangsa.

\section{Pembentukan Identitas Masyarakat Dataran Tinggi Dieng}

Pembentukan identitas masyarakat dataran tinggi Dieng terjadi padadua aras sosial yaitu meso dan makro.Pembentukan identitas pada aras meso dilakukan oleh Kelompok Sadar Wisata (Pokdarwis). Lembaga ini berfungsi sebagai forum komunikasi masyarakat pariwisata Kawasan Dataran Tinggi Dieng. Lembaga ini berperan penting dalam melestarikan serta mengangkat fenomena dan mitos rambut gimbal sebagai ikon budaya. Upaya yang dilakukan oleh Pokdarwis adalah menyelenggarakan pekan budaya bertajuk Dieng Culture Festival serta mendirikan Desa Wisata. Upaya tersebut berhasil mengubah stigma negatif anak rambut gimbal yang semula dianggap sukerta atau masalah menjadi sebuah berkah. Selain itu, menjadikan mitos rambut gimbal banyak diketahui oleh khalayak ramai, sehingga diakui sebagai identitas masyarakat dataran tinggi Dieng oleh masyarakat luas.

Pembentukan identitas di aras makro dilakukan oleh pemerintah. Pemerintah menjadikan kekhasan budaya masyarakat dataran tinggi Dieng, yaitu rambut gimbal, sebagai daya tarik wisata melalui legitimasi ekonomi dan politik. Latar belakang pemerintah berupaya menjadikan mitos rambut gimbal sebagai identitas masyarakat dataran tinggi Dieng adalah pelestarian, kesejahteraan, dan pendapatan. Pariwisata menjadi sarana pelestarian budaya sekaligus meningkatkan kesejahteraan masyarakat dan Pendapatan Asli Daerah (PAD). Pariwisata menjadi lebih menarik tatkala ditunjang dengan kearifan lokal, tradisi, serta budaya masyarakatnya. Oleh karena itu, mitos rambut gimbal sebagai warisan budaya yang dimiliki oleh masyarakat dilegitimasi oleh pemerintah untuk meningkatkan daya tarik wisata.

Sementara itu, pembentukan identitas justru tidak terjadi di aras mikro. Upacara tradisi ruwat rambut gimbal sebetulnya dapat dilakukan setiap keluarga. Tujuannya tentu saja tidak berkaitan dengan pembentukan identitas, tetapi lebih pada kepentingan untuk meraih keselamatan bagi anak rambut gimbal. Banyak keluarga dari anak rambut gimbal yang tidak mau mengikutsertakan anaknya pada penyelenggaraan upacara tradisi ruwat rambut gimbal massal yang akhir-akhir ini sering diselenggarakan oleh Pokdarwis bekerjasama dengan pemerintah daerah. Jikalau ada keluarga yang mengikutsertakan anaknya dalam upacara cukur massal, tujuan mereka bukanlah pada aspek materi.

Perlu digarisbawahi bahwa pembentukan identitas pada ketiga aras ini merupakan proses yang berkesinambungan sehingga tidak pernah terselesaikan secara tuntas. Mitos rambut gimbal telah menjadi kekhasan identitas masyarakat dataran tinggi Dieng. Di dalam perkembangan pariwisata, kekhasan identitas ini dijadikan sebagai komoditas. Pada tahap inilah komodifikasi budaya terjadi.

\section{Komodifikasi Mitos Rambut Gimbal}

Komodifikasi merupakan upaya memberikan nilai kepada suatu obyek agar obyek tersebut dapat diperjual-belikan. Sharp (2000) dan Malmqvist (2012), menyatakan bahwa tubuh manusia dan bagian-bagiannya telah lama menjadi sasaran komodifikasi dalam berbagai setting budaya. Rambut gimbal dalam hal ini dapat dilihat sebagai bagian dari tubuh manusia yang dijadikan sebagai komoditas pariwisata oleh masyarakat dan pemerintah.

Pada mulanya, upacara tradisi ruwat rambut gimbal hanya dilakukan sendiri di lingkup keluarga. Namun, pada perkembangannya, upacara tradisi tersebut diselenggarakan secara massal pada acara Dieng Culture Festival (DCF). Penyelenggaran upacara tradisi ruwat rambut gimbal massal menimbulkan pro dan kontra di masyarakat. Di satu sisi, ruwatan massal dianggap sebagai bentuk pelestarian budaya, yang 
berdampak mensejahterakan masyarakat, dan meningkatkan Pendapatan Asli Daerah (PAD). Di sisi lain, ruwatan massal dianggap sebagai penyebab pudarnya keotentikan, kesakralan dan keaslian ruwatan. Alih-alih menjadi sebuah upaya pelestarian budaya, ruwatan massal menjadi kegiatan yang bertujuan meraih keuntungan finansial. Pendapat ini dapat dikaitkan dengan konteks kapitalisme. Kapitalisme telah mengubah budaya menjadi bagian dari industri (Shepherd, 2002). Pada saat mitos rambut gimbal dijadikan komoditas pariwisata, kapitalisasi budaya pun terjadi. Masyarakat pemilik mitos rambut gimbal menjadi produsen, pemerintah sebagai distributor dan marketing, serta khalayak ramai menjadi konsumen.

Pariwisata budaya dapat merusak nilai-nilai serta sendi-sendi kemurnian mitos rambut gimbal. Sebab, mitos rambut gimbal harus disesuaikan dengan trend pasar. Pasarlah yang menentukan produk yang layak untuk dijual dan diterima oleh konsumen. Ironi terjadi manakala mitos rambut gimbal dipromosikan tanpa upaya untuk menjaga kemurniannya. Mitos rambut gimbal dapat dijadikan promosi wisata, tetapi harus selalu tetap dijaga kemurniannya. Masyarakat, pemangku adat, dan pemerintah perlu berperan dalam melindungi kemurnian mitos rambut gimbal. Selain itu, peran berbagai pihak dalam hal mensosialisasikan kearifan yang terkandung dalam mitos rambut gimbal kepada generasi selanjutnya dengan tetap mempertimbangkan keautentikan, keaslian, dan kesakralan adalah hal yang sangat penting.

\section{Simpulan}

Dari seluruh pembahasan diatas, dapat disimpulkan bahwa upaya pembentukan identitas masyarakat dataran tinggi Dieng melalui mitos rambut gimbal, paling kuat terjadi di tingkat lembaga masyarakat (aras meso) yaitu Kelompok Sadar Wisata (Pokdarwis). Mitos rambut gimbal sebelum dibentuk sebagai identitas masyarakat dataran tinggi Dieng belum banyak diketahui oleh masyarakat luas. Sekarang mitos rambut gimbal telah menjadi identitas masyarakat dataran tinggi Dieng. Pokdarwis berperan dalam melestarikan dan mempromosikan mitos rambut gimbal sebagai komoditas pariwisata.

Pembentukan identitas pada aras meso tidak dapat terbangun jika aras mikro-individu (keluarga pemilik rambut gimbal) tidak mengakui mitos rambut gimbal sebagai bagian dari identitas mereka. Selain itu, mitos rambut gimbal sebagai identitas masyarakat dataran tinggi Dieng tidak akan terjadi apabila pada aras makro (Pemerintah) tidak ikut membentuk dan membangun mitos rambut gimbal sebagai identitas. Jadi, antara aras makro, meso, dan mikro saling melengkapi satu sama lain.

Komodifikasi mitos rambut gimbal dapat dimanfaatkan untuk melestarikan budaya sekaligus memberikan manfaat ekonomi bagi masyarakat dataran tinggi Dieng. Namun, kesakralan, keaslian, dan maknanya dapat memudar seiring dengan permintaan pasar. Oleh karena itu, perlu dukungan dari berbagai pihak untuk menjaga keaslian dari mitos rambut gimbal ditengah momodifikasi mitos.

\section{Daftar Pustaka}

Ahimsa-Putra, Heddy Shri. 2001. Strukturalisme Lévi-Strauss: Mitos dan Karya Sastra. Yogyakarta: Galang Press.

Arif, Moh. Choirul. 2013. Makna Simbolik Rambut gimbal. Jurnal Ilmu Komunikasi, Vol 3 No. 02.

Barker, Chris. 2013. Cultural Studies, Teori dan Praktik. Terjemahan Nurhadi. Yogyakarta: Kreasi Wacana.

Barth, Fredrik. 1988. Kelompok Etnik dan Batasannya: Tatanan Sosial dari Perbedaan Kebudayaan. Terjemahan Nining I. Soesilo. Jakarta: UI-Press.

Boissevain, J. (1996a) 'Introduction', in Coping with Tourists. Oxford: Berghahn. (1996b) 'Ritual, Tourism and Cultural Commoditization in Malta: Culture by the Pound?', in T. Selwyn (ed.) The Tourist Image: Myths and Myth Making in Tourism. Chichester: Wiley and Sons. 
Callister, P., Didham, R. dan Kivi, A. Who are we? The conceptualisation and expression of ethnicity. Official Statistics Research Series, Vol-4. 2009. Available from http://www.statisphere.govt.nz/officialstatisticsresearch/series/default.htm

Creswell, W. John. 2010. Research Design: Pendekatan Kualitatif, Kuantitatif, dan Mixed ( $3^{\text {rd }}$ Ed.). Terjemahan Achmad Fawaid. Yogyakarta: Pustaka Pelajar.

Daeng, Hans J. 2008. Manusia, Kebudayaan, dan Lingkungan: Tinjauan Antropologis. Yogyakarta: Pustaka Pelajar.

Damayanti, Puspa Ayu. 2011. Dinamika Perilaku "Nakal" Anak Berambut Gimbal Di Dataran Tinggi Dieng. Psikoislamika, Jurnal Psikologi Islam (JPI), Vol. 8 No. 2: 165-190.

Dandirwalu, Resa. 2008. Mitos Asal Usul Orang Nias dalam Konteks Masa Kini: Suatu Tinjauan Fenomenologi-Hermeneutik Pada Masyarakat di Desa Sifalagö Gomo (Börönadu). (Tesis). Universitas Gajah Mada.

Dinas Pariwisata Dan Kebudayaan Kabupaten Wonosobo. 2013. Upacara-Upacara Tradisi Di Kabupaten Wonosobo. Wonosobo: Dinas Pariwisata Dan Kebudayaan Kabupaten Wonosobo.

Endraswara, Suwardi. 2006. Metode Penelitian Kebudayaan (Revised Ed.). Yogyakarta: Gajah Mada University Press.

Eriksen, Thomas Hylland. 2010. Ethnicity and Nationalism: Anthropological Perspectives $\left(3^{\text {rd }}\right.$ Ed.). Pluto Press.

Fauzan, Ahmad. 2013. Mitologi Asal Usul Orang Sasak: Analisis Struktural Pemikiran Orang Sasak dalam Tembang Doyan Neda. (Tesis). Universitas Gajah Mada.

Greenwood, D. (1989) 'Culture by the Pound: An Anthropological Perspective on Tourism as Cultural Commoditization', in V.L. Smith (ed.) Hosts and Guests: The Anthropology of Tourism. Philadelphia: University of Pensylvania Press.

Hutchinson, John. dan Smith, Anthony D. (Editor). 1996. Ethnicity. New York: Oxford University Press.

Kirtsoglou, Elisabeth dan Theodossopoulos, Dimitrios. They are Taking our Culture Away, Tourism and Culture Commodification in the Garifuna Community of Roatan. Critique of Anthropology. Vol 24 (2). Hal 135-157. 2004.
Koentjaraningrat. 1958. Metode-Metode Dalam Penyelidikan Masyarakat dan Kebudayaan di Indonesia. Jakarta: Penerbitan Universitas.

Leni, Nurhasanah. 2004. Analisis Struktural Lévi-Strauss dan Mitos Tasawuf. (Tesis). Universitas Gajah Mada.

Lévi-Strauss, Claude. 1958. Antropologi Struktural. Translated by Ninik Rochani Sjams. 2013 (Cet. IV). Yogyakarta: Kreasi Wacana.

Macleod, D. (1999) 'Tourism and the Globalization of a Canary Island', Journal of the Royal Anthropological Institute (n.s.) 5: 443-56.

Malmqvist, Erik. 2012. Trading Hair, Trading Cadaver Tissue: On the Ethics of Commodifying Bodily Sacrifices and Gifts. Dalam Gunnarson, Martin dan Svenaeus, Fredrik. (Editor) The Body As Gift, Resource, And Commodity: Exchanging Organs, Tissues, And Cells In The 21st Century. Hlm 296-320. Stockholm: E-Print.

Martiarini, Nuke. 2011. Studi Pustaka Ruwatan Cukur Rambut gimbal Sebagai Symbolic Healing Di Dataran Tinggi Dieng Wonosobo. Psikohumanika, Vol. IV, No. 1. 2011

Mutmainah, Siti. 2013. "Perilaku Sosial Anak Usia Dini Berambut Gimbal Di Daerah Dataran Tinggi Dieng Kabupaten Wonosobo". Early Childhood Education Papers ( Belia), 2 (1) : 48-55.

Pemerintah Desa Dieng. tanpa tahun. Profil Desa Wisata Desa Dieng. Desa Dieng Kecamatan Kejajar Kabupaten Wonosobo Jawa Tengah Indonesia.

Sharp, Lesley A. The Commodification of The Body and Its Parts. Annual Reviews of Anthropology. Vol 29. Hal 287-328. 2000. Diunduh dari arjournals.annualreviews.org oleh University of California-San Diego on 06/25/09.

Shepherd, Robert. Commodification, Culture, and Tourism. Tourist Studies, 2; 183. 2002. Diunduh dari: SAGE Publication http://tou.sagepub.com/cgi/content/abstract /2/2/183 pada 3 januari 2008.

Soehadha, Moh. 2013. Ritual Rambut gimbal dalam Arus Ekspansi Pasar Pariwisata. Walisongo, Vol. 21 No. 2: 347-364.

Spradley, James P. 1997. Metode Etnografi. Translated by Misbah Zulfa Elisabeth. 1997. Yogyakarta: PT. Tiara Wacana Yogya. 
1979. The Ethnographic

Interview. USA: Holt, Rinehart and Winston.

1980. Participant

Observation. USA: Holt, Rinehart and Winston.

Tilley, C. (1997) 'Performing Culture in the Global Village', Critique of Anthropology 17(1): 67-89.

Widiyanto, Nur. 2012. Berlindung di Balik Mitos: Mitos Maslihe dan Adaptasi Kultural Penduduk Kendahe, Kepulauan Sangihe Terhadap Bahaya Letusan Gunung Awu. (Tesis). Universitas Gajah Mada.

van Peursen, C. A. 1988. Strategi Kebudayaan. Terjemahan Dick Hartoko. Yogyakarta: Kanisius.

Zöllner, Sigfried. 2011. Pohon Yeli dan Mitos Wam dalam Agama Orang Yali. Wahine. 